\title{
Article
}

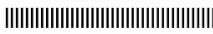

\section{Investigation of Tritium and Radiocaesium in Spring Water and Short Precipitation after the Fukushima Dai-ichi Nuclear Power Plant Accident}

\author{
Ying $\mathrm{WANG}^{\dagger}$, Noriaki KATAOKA, Naoyuki KANDA, RyutaYAmAdA, \\ Minami W at Anabe, Shogo Morit A, Hiroshi Imaizumi and Naoki Kano \\ Graduate School of Science and Technology, Niigata University \\ Ikarashi 2-no-cho, Nishi-ku, Niigata-shi, Niigata Pref. 950-2181, Japan \\ ${ }^{\dagger}$ analysis@eng.niigata-u.ac.jp \\ Received January 27, 2015
}

Accepted July 2, 2015

\begin{abstract}
Hydrogen explosion occurred at Fukushima Dai-ichi nuclear power plants in Japan on 12-15 th March, 2011. At the same time, lots of radioactive materials have been released including tritium $(\mathrm{T})$, and caused serious environmental impacts. In order to investigate the effect of the accident of Fukushima Dai-ichi nuclear power plant on environment, we collected the short precipitation (hourly collected precipitation) and spring water for several years after the accident. As to the precipitation collected, $\mathrm{T}$ and radiocaesium were measured by using liquid scintillation counter and high-purity germanium detector, respectively. Furthermore, we also measured the concentration of ions $\left(\mathrm{Na}^{+}, \mathrm{Cl}^{-}, \mathrm{Ca}^{2+}\right.$, and $\left.\mathrm{SO}_{4}{ }^{2-}\right)$ in spring water. From the abovementioned matters, the following points have been obtained:(1) The variation of $\mathrm{T}$ concentration in recent three years (2012, 2013 and 2014) can be clarified. (2) The effect of the accident on spring water in mountains around the Fukushima prefecture is so small. (3) As to the short precipitation on 15 th March, 2011, the activity of radiocaesium was not detected, but the activity of $\mathrm{T}$ was detected significantly.
\end{abstract}

Key Words : Fukushima Dai-ichi nuclear power plant, short precipitation, spring water, tritium, radiocaesium

\section{Introduction}

Tritium ( ${ }^{3} \mathrm{H}$ or $\left.\mathrm{T}\right)$, is one of hydrogen isotopes and is one of radioactive materials as natural and artificial ones ${ }^{1-6)}$. The naturally occurring levels of $T$ can be produced by the interaction of cosmic ray with the atmosphere, and its physical half-life is 12.3 years $^{7}$. Additional sources are from fallout from weapons testing and ternary fission in general nuclear power reactor.

The HTO vapor is formed readily from HT gas, and is one of the most common radioactive materials in the environment $t^{8)}$. Price (1958) clarified that, in the range of 25 to $80^{\circ} \mathrm{C}$, the vapor pressure of HTO is less than that of $\mathrm{H}_{2} \mathrm{O}$, and that HTO has a higher boiling point than $\mathrm{H}_{2} \mathrm{O}^{9)}$. $\mathrm{T}$ closely acts as the reactions of ordinary hydrogen $\left({ }^{1} \mathrm{H}\right)$, but has the relatively large differences in isotopic effects. Because of the importance of water in the life processes, $T$ concentration (i.e., the specific activity of $\mathrm{T}$ ) in water is of special concern ${ }^{10)}$.

On $12^{\text {th }}$ March, 2011, the nuclear accident occurred at Fukushima, Japan after large earthquake (Higashinihon disaster). In the accident, 
Table 1 Sampling points of several mountains in 2012, 2013 and 2014

\begin{tabular}{lllll}
\hline & \multicolumn{2}{c}{ Date } & \multicolumn{1}{c}{ Location } \\
\hline 1 & 2012.8 .30 & 2013.9 .13 & 2014.7 .15 & Hijikatadairaosyouzu (Mt. Azuma) \\
2 & 2012.8 .30 & 2013.9 .13 & 2014.7 .15 & Ondennokami (Mt. Zao) \\
3 & 2012.8 .30 & 2013.9 .13 & 2014.7 .15 & Zaosanchofukin (Mt. Zao) \\
4 & 2012.8 .30 & 2013.9 .13 & 2014.7 .15 & Kuraishidakeidosawafukin (Mt. Zao) \\
5 & 2012.8 .28 & 2013.9 .12 & 2014.7 .15 & Kinmeisui (Mt. Adatara) \\
6 & 2012.8 .31 & 2013.9 .12 & 2014.7 .16 & Ougonshimizu (Mt. Bandai) \\
\hline
\end{tabular}

increasing of $\mathrm{T}$ concentration has lots of worry and the influence on environment should be considered. In addition, as to the areas which affected by the monsoon and the seasonal effect (e.g., spring peak) ${ }^{11}$, the kinds of ion concentrations should be almost measured ${ }^{12), 13)}$ to clarify whether the obtained results affected by seasonal variation. Considering the abovementioned matters, we observed $\mathrm{T}$ and major elements $\left(\mathrm{Na}^{+}, \mathrm{Cl}^{-}, \mathrm{Ca}^{2+}\right.$, and $\left.\mathrm{SO}_{4}{ }^{2-}\right)$ to find out the effects of concentration of these elements on the environment.

In this work, $\mathrm{T}$ and radiocaesium concentrations in short precipitation (hourly collected precipitation) and spring water were investigated. The analytical methods were followed by the method of the Japan Chemical Analysis Center manual ${ }^{14)}$.

\section{Experimental}

$2 \cdot 1$ Standard, reagents and materials

$\mathrm{T}$ water (specific activity $3.7 \times 10^{7} \mathrm{~Bq} \cdot \mathrm{cm}^{-3}$ ) was purchased from Japan Radioisotope Association, and was used to determine the T detection efficiency.

The standard solutions of $\mathrm{Na}^{+}, \mathrm{Ca}^{2+}, \mathrm{Cl}^{-}$and $\mathrm{SO}_{4}{ }^{2-}$, etc. were prepared by diluting a 1000 $\mathrm{mg} \cdot \mathrm{dm}^{-3}$ standard solution, respectively. These standard solutions $\left(1000 \mathrm{mg} \cdot \mathrm{dm}^{-3}\right)$ were purchased from KANTO CHEMICAL in Japan.
For the distillation of sample water, GR grade $\mathrm{Na}_{2} \mathrm{O}_{2}$ from Wako Pure Chemical and $\mathrm{KMnO}_{4}$ purchased from KANTO CHEMICAL were supplied in the distillation bottle. After being distilled, each sample was subsequently enriched by electrolytic enrichment method ${ }^{15)}$ (SPE method). After electrolytic enrichment, $30 \mathrm{~mL}$ of the enriched sample was introduced into $145 \mathrm{~mL}$ polyethylene scintillation vial provided from ZINSSER ANALYTIC, Germany, and $70 \mathrm{~mL}$ of the liquid scintillation cocktail was added.

\section{$2 \cdot 2$ Samples}

The sampling date of each spring water (Fukushima prefecture and the adjacent prefectures) is shown in Table 1, and the location of each sampling point for collecting spring water is also shown in Fig. 1(a). In this study, the water samples were collected in August, 2012, September, 2013, and July, 2014, respectively.

Each short precipitation was collected in large plastic sampler on $15^{\text {th }}$ May, 2011 at Niigata University $\left(37.87^{\circ} \mathrm{N}, 138.94^{\circ} \mathrm{E}\right)$. Each sample water was collected hourly. And each point of air dose rate is shown in Fig. 1(b).

$2 \cdot 3$ Sample pretreatment and measurement

$\mathrm{T}$ concentration of each enriched sample added scintillation cocktail (Ultima Gold) was 


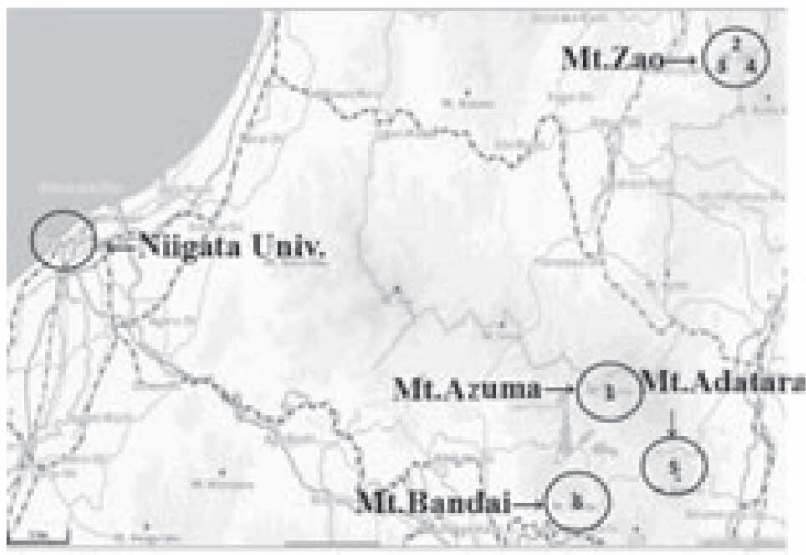

Fig. 1 (a) Spring water sampling sites in Fukushima and the adjacent prefecture.

1. Hijikatadairaosyouzu (Mt. Azuma)

2. Ondennokami(Mt. Zao)

3. Zaosanchofukin (Mt. Zao)

4. Kuraishidakeidosawafukin (Mt. Zao)

5. Kinmeisui (Mt. Adatara)

6. Ougonshimizu (Mt. Bandai)

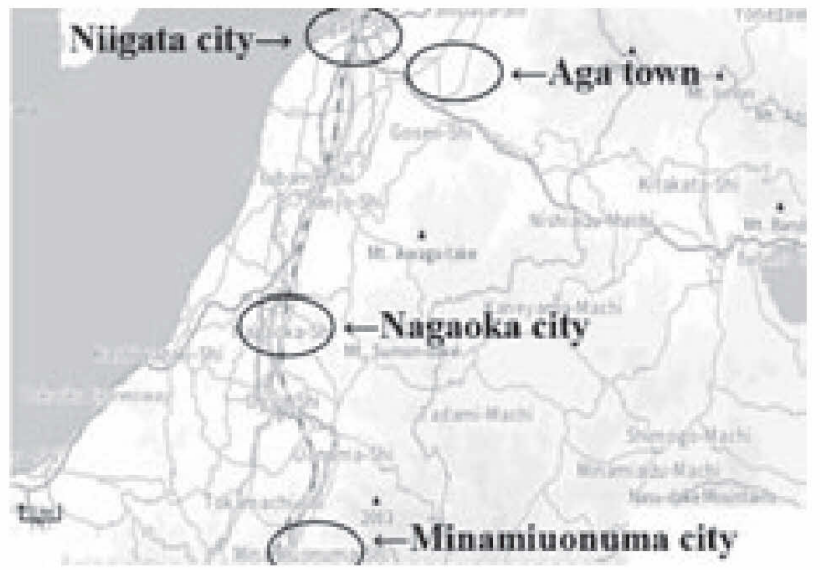

Fig. 1 (b) The measuring sites of air dose rate.

measured by low-background liquid scintillation counter (LCS, Aloka Co., Ltd., Japan).

In addition, the radioactivity of short precipitation was measured using a p-type high-purity germanium detector (GC4020-7500SL, Canberra, USA) with a multi-channel analyzer
(Lynx, Genie 2000, Canberra, USA). The analyzed radionuclides by gamma-ray spectrometry were ${ }^{137} \mathrm{Cs}(661.7 \mathrm{keV})$ and ${ }^{134} \mathrm{Cs}(604.7$ and $795.6 \mathrm{keV})$. 


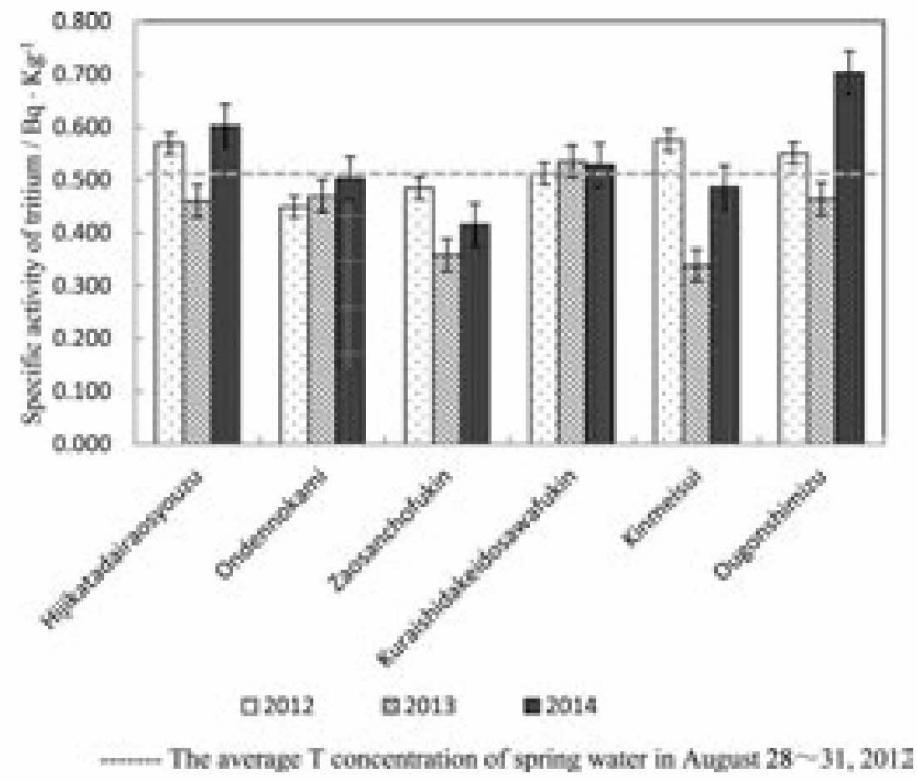

Fig. 2 Specific activity of $\mathrm{T}$ in each mountain.

\section{Results and discussion}

$3 \cdot 1$ The specific activity of $\mathrm{T}$ ( $\mathrm{T}$ concentration) in sample water in each mountain

Each result of $\mathrm{T}$ measurement is shown in Fig. 2. The broken line shows the average $\mathrm{T}$ concentration of spring water in August 28 31, 2012.

Using the collector of initial ground water ${ }^{16), 17)}$, monthly precipitations were collected, and the recent annual average (2012, 2013 and 2014) of $\mathrm{T}$ concentration in precipitation in Niigata (at Niigata University) is 0.51 $\pm 0.21 \mathrm{~Bq} \cdot \mathrm{kg}^{-1}$ (Table 2 ).

In previous report $\mathrm{t}^{18)}$, in general, the residence time of spring water in lower mountain and around the top of mountain is about 2 to 3 years in Tohoku. Comparing of $\mathrm{T}$ concentrations in 2012, 2013 and 2014 with each other, it is found each $\mathrm{T}$ concentration of spring water is similar to each other.

In addition, it is also shown that the $\mathrm{T}$ concentration in 2014 tends to be higher than that in 2013. Although the $\mathrm{T}$ concentration in 2014 is slightly higher, it may depends on variation of $\mathrm{T}$ concentration in the environment. Overall, the $\mathrm{T}$ concentration remained almost stable, so the difference may be affected by Fukushima Dai-ichi nuclear accident, but it can be thought that the influence of the Fukushima Dai-ichi

Table 2 Monthly specific activities of $\mathrm{T}[\mathrm{Bq}$. $\mathrm{kg}^{-1}$ in precipitation from 2012 to 2014 in Niigata city (at Niigata University), Japan

\begin{tabular}{cccc}
\hline Month/Year & 2012 & 2013 & 2014 \\
\hline Jan & 0.719 & 0.356 & 0.407 \\
Feb & 0.660 & 0.539 & 0.456 \\
Mar & 0.967 & 0.740 & 0.635 \\
Apr & 0.689 & 0.897 & 0.834 \\
May & 0.858 & 0.476 & 0.708 \\
Jun & 0.496 & 0.514 & 0.351 \\
Jul & 0.493 & 0.361 & 0.456 \\
Aug & 0.292 & 0.453 & 0.217 \\
Sep & 0.294 & --- & 0.249 \\
Oct & 0.357 & 0.859 & 0.484 \\
Nov & 0.361 & 0.324 & 0.521 \\
Dec & 0.112 & 0.232 & 0.325 \\
\hline
\end{tabular}



after the Fukushima Dai-ichi nuclear power plant accident
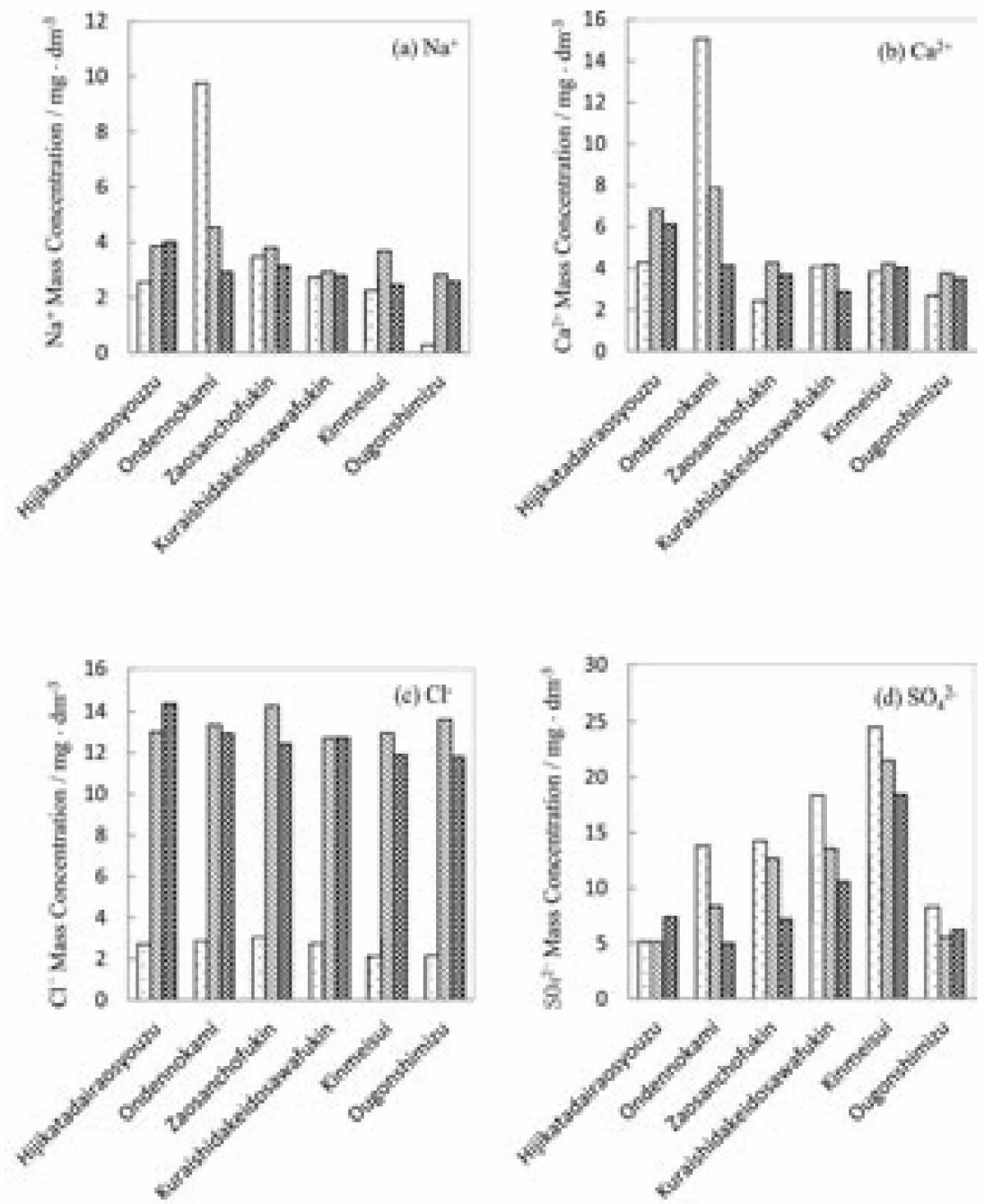

Fig. 3 The concentrations of several ions in each location.

nuclear accident are so small.

\section{$3 \cdot 2$ The concentrations of several ions in} each location

The major ions in spring water such as $\mathrm{Na}^{+}$, $\mathrm{Ca}^{2+}, \mathrm{Cl}^{-}$and $\mathrm{SO}_{4}{ }^{2-}$ were measured in August, 2012, September, 2013 and July, 2014.

Measurement results of four different ions in spring water (at six different locations in
Fukushima prefecture and the adjacent prefectures) are shown in Fig. 3 a-d, and the concentrations of ions are summarized in Table 3. From the figures, it is found that $\mathrm{Cl}^{-}$concentration is high compared with other ions. In general, $\mathrm{Cl}^{-}$concentration in sea water is higher than that in the precipitation, so the sample in spring may be influenced by sea water. 
Table 3 Specific activities of $\mathrm{T}$ and several ion concentrations in spring water from different mountains around Fukushima

\begin{tabular}{|c|c|c|c|c|c|c|}
\hline \multirow[t]{2}{*}{ Location } & \multirow[t]{2}{*}{ Date } & \multirow{2}{*}{$\frac{\mathrm{T}}{\mathrm{Bq} \cdot \mathrm{kg}^{-1}}$} & $\mathrm{Na}^{+}$ & $\mathrm{Ca}^{2+}$ & $\mathrm{Cl}^{-}$ & $\mathrm{SO}_{4}{ }^{2-}$ \\
\hline & & & \multicolumn{4}{|c|}{$\mathrm{mg} \cdot \mathrm{dm}^{-3}$} \\
\hline \multirow{3}{*}{$\begin{array}{c}\text { Hijikatadairaosyouzu } \\
\text { (Mt. Azuma) }\end{array}$} & 2012.8 .30 & $0.57 \pm 0.06$ & 2.6 & 4.3 & 2.7 & 5.2 \\
\hline & 2013.9 .13 & $0.46 \pm 0.05$ & 3.9 & 6.8 & 13 & 5.6 \\
\hline & 2014.7.15 & $0.60 \pm 0.04$ & 4.0 & 6.1 & 14 & 7.4 \\
\hline \multirow{3}{*}{$\begin{array}{l}\text { Ondennokami } \\
\text { (Mt. Zao) }\end{array}$} & 2012.8 .30 & $0.45 \pm 0.05$ & 9.8 & 15 & 2.9 & 14 \\
\hline & 2013.9 .13 & $0.47 \pm 0.05$ & 4.5 & 7.9 & 13 & 8.4 \\
\hline & 2014.7 .15 & $0.50 \pm 0.05$ & 2.9 & 4.2 & 13 & 5.0 \\
\hline \multirow{3}{*}{$\begin{array}{l}\text { Zaosanchofukin } \\
\text { (Mt. Zao) }\end{array}$} & 2012.8 .30 & $0.48 \pm 0.05$ & 3.5 & 2.5 & 3.0 & 14 \\
\hline & 2013.9.13 & $0.36 \pm 0.04$ & 3.9 & 4.3 & 14 & 13 \\
\hline & 2014.7 .15 & $0.41 \pm 0.05$ & 3.2 & 3.7 & 12 & 7.2 \\
\hline \multirow{3}{*}{$\begin{array}{l}\text { Kuraishidakeidosawafukin } \\
\text { (Mt. Zao) }\end{array}$} & 2012.8 .30 & $0.51 \pm 0.06$ & 2.7 & 4.1 & 2.8 & 18 \\
\hline & 2013.9 .13 & $0.54 \pm 0.06$ & 2.9 & 4.2 & 13 & 14 \\
\hline & 2014.7 .15 & $0.53 \pm 0.04$ & 2.8 & 2.9 & 13 & 11 \\
\hline \multirow{3}{*}{$\begin{array}{l}\text { Kinmeisui } \\
\text { (Mt. Adatara) }\end{array}$} & 2012.8 .28 & $0.58 \pm 0.06$ & 2.2 & 3.8 & 2.1 & 25 \\
\hline & 2013.9.12 & $0.34 \pm 0.04$ & 3.7 & 4.2 & 13 & 22 \\
\hline & 2014.7.15 & $0.49 \pm 0.04$ & 2.5 & 4.0 & 12 & 18 \\
\hline \multirow{3}{*}{$\begin{array}{l}\text { Ougonshimizu } \\
\text { (Mt. Bandai) }\end{array}$} & 2012.8 .31 & $0.55 \pm 0.06$ & 0.3 & 2.7 & 2.2 & 8.3 \\
\hline & 2013.9 .12 & $0.46 \pm 0.05$ & 2.8 & 3.8 & 14 & 5.6 \\
\hline & 2014.7 .16 & $0.70 \pm 0.04$ & 2.6 & 3.5 & 12 & 6.2 \\
\hline
\end{tabular}

The above-mentioned shows that Japanese atmosphere is strongly affected by sea water, especially in spring and winter seasons ${ }^{13)}$.

Moreover, six different locations had similar concentration of $\mathrm{Na}^{+}$and $\mathrm{Ca}^{2+}$, so they are subjected to similar influences from sea water.

It is also found that in Kinmeisui had much higher concentration of $\mathrm{SO}_{4}{ }^{2-}$ than other five locations. $\mathrm{SO}_{4}{ }^{2-}$ may come from Mt. Bandai. Bandai is a famous volcano.

The change of $\mathrm{T}$ concentration along with the ion concentrations change at the same time in spring water (especially $\mathrm{Ca}^{2+}$ concentration) ${ }^{11)}$. It was through that the variations of ion concentrations in spring water for these three years show the similar yearly variation, and also show the effect of the accident is so small.

\section{$3 \cdot 3$ Short precipitation}

On $15^{\text {th }}$ March 2011, we collected the short precipitation and the $\mathrm{T}$ concentration was measured (Fig.4). In addition, radiocaesium concentrations were measured (Table 4), and air dose rates $(\mu \mathrm{Sv} / \mathrm{h})$ in Niigata city at the same time are shown in Fig. 5. The detail obtained by using monitoring post ${ }^{19)}$. As to these samples, radiocaesium was not detected, but $\mathrm{T}$ concentration was increasing during 17:3018:30. The increasing of the air dose rate in Niigata city was not observed clearly, but in Agano and Minamiuonuma city, the rates increased. From these results, a few radioactive plume reached in Niigata city via Minamiuonuma city. It seems that radiocaesium was almost washed out in Minamiuonuma and Agano city. However, only $\mathrm{T}$ was reached at Niigata city, because $\mathrm{T}$ is diffused more easily 


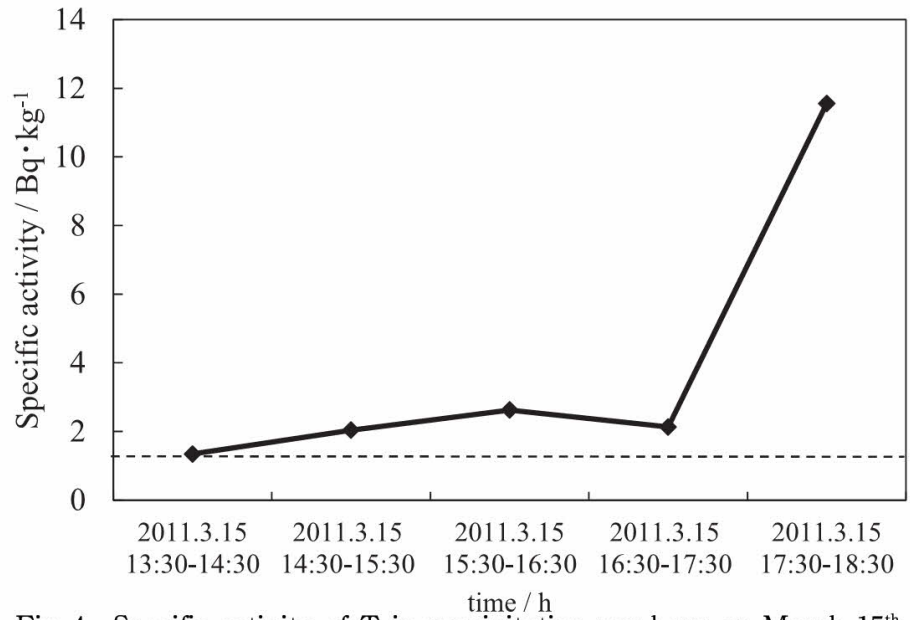

Fig. 4 Specific activity of $T$ in precipitation per hour on March $15^{\text {th }}$, 2011, rooftop of faculty of Niigata University, Niigata, Japan.

Table 4 Specific activities of $\mathrm{T}$ and radiocaesiums, and air dose rate in Nigata city

\begin{tabular}{|c|c|c|c|c|}
\hline & $\mathrm{T} / \mathrm{Bq} \cdot \mathrm{kg}^{-1}$ & ${ }^{134} \mathrm{Cs} / \mathrm{Bq} \cdot \mathrm{kg}^{-1}$ & ${ }^{137} \mathrm{Cs} / \mathrm{Bq} \cdot \mathrm{kg}^{-1}$ & Air dose rate $/ \mu \mathrm{Sv} \cdot \mathrm{h}^{-1}$ \\
\hline $\begin{array}{l}2011.3 .15 \\
13: 30 \sim 14: 30\end{array}$ & $1.3 \pm 0.2$ & $<0.1$ & $<0.1$ & 0.049 \\
\hline $\begin{array}{l}2011.3 .15 \\
14: 30 \sim 15: 30\end{array}$ & $2.0 \pm 0.1$ & $<0.1$ & $<0.1$ & 0.050 \\
\hline $\begin{array}{l}2011.3 .15 \\
15: 30 \sim 16: 30\end{array}$ & $2.6 \pm 0.1$ & $<0.1$ & $<0.1$ & 0.048 \\
\hline $\begin{array}{l}2011.3 .15 \\
16: 30 \sim 17: 30\end{array}$ & $2.1 \pm 0.2$ & $<0.1$ & $<0.1$ & 0.049 \\
\hline $\begin{array}{l}2011.3 .15 \\
17: 30 \sim 18: 30\end{array}$ & $12 \pm 0.5$ & $<0.1$ & $<0.1$ & 0.051 \\
\hline
\end{tabular}

than other radionuclide.

\section{Conclusions}

In recent three years, the measurements of $\mathrm{T}$ concentration and four major ions in spring water of Fukushima and short term precipitation in Niigata provide the important informations of environment by Fukushima Dai-ichi nuclear accidents.

In this study, the following main conclusions have been obtained :

(1) The variation of $\mathrm{T}$ concentration in 2012 , 2013 and 2014 was clarified. T concentra- tion in each year nearly equals the annual average of normal $\mathrm{T}$ concentration in Niigata $\left(0.51 \pm 0.21 \mathrm{~Bq} \cdot \mathrm{kg}^{-1}\right)$ obtained in the same year.

(2) Chloride ion concentration was higher in spring water, therefore it is considered the sample in spring was influenced by sea water, and also considered Japanese atmosphere is strongly affected by sea water.

(3) As to each short precipitation sample collected on March $15^{\text {th }}, 2011$, the T concentration of each sample gathered during 


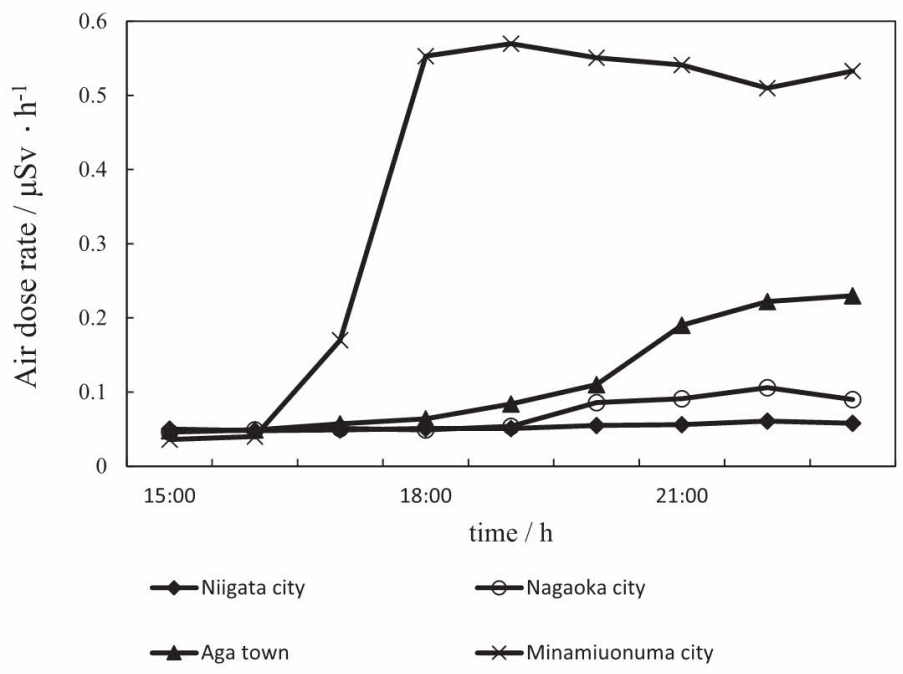

Fig. 5 Air dose rate in Niigata on $15^{\text {th }}$ March 2011.

$13: 30-17: 30$ was about $2 \mathrm{~Bq} / \mathrm{kg}$, but the concentration during 17:30-18:30 PM was about $12 \mathrm{~Bq} / \mathrm{kg}$. So, Niigata city was temporarily affected by the accident.

(4) It seemed that radiocaesium was washed out in Minamiuonuma and Agano city after the accident. However, only $\mathrm{T}$ reached Niigata city because $\mathrm{T}$ is diffused more easily than other radionuclides.

(5) It can be concluded that the effect of the accident of Fukushima Dai-ichi Nuclear Power Plants on Niigata city is small.

(6) These data thus obtained is useful to evaluate the effect of the accident of Fukushima Dai-ichi Nuclear Power Plant on the environment.

\section{References}

1) Clark, I. D. and Fritz, P., Environmental Isotopes in Hydrogeology, CRC Press, Florida (1997)

2) Cris, R. E., Principles of Stable Isotope Distribution, Oxford University Press, New York (1999)

3) Dansgaard, W., Stable isotopes in precipitation, Tellus, 16, 436-468(1964)

4) Yurtsever, Y. and Gat, J. R., Atmospheric waters, in : Gat, J. R. and Gonfiantini, R. (Eds.), Stable Isotope Hydrology: Deuterium and Oxygen-18 in the Water Cycle, IAEA, Technical Reports Series, Vol. 210, 103-142 (1981)

5) Ravikumar, P. and Somashekar, R. K., Environmental tritium and hydrochemical investigations to evaluate groundwater in Varahi and Markandeya river basins, Karnataka, India, J. Environ. Radioact., 102 (2), 153-162(2011)

6) Paneth, F. A., Use of radioactive tracers in biological research, Nature, 163, 388-390 (1949)

7) Lucas, L. L. and Unterweger, M. P., J. Res. Nat. Inst. Stand. Technol., 105, 541-549 (2000)

8) Choi, Y. H., Lim, K. M., Lee, W. Y., Diabate, S. and Strack, S., Tissue free water tritium and organically bound tritium in the rice plant acutely exposed to atmospheric HTO vapor under semioutdoor conditions, J. Environ. Radioact., 58, 67-85 (2002)

9) Tritium in the environment, National Council on Radiation and Measurements, NCRP REPORT No.62

10) Hisamitsum, S. and Takizawa, Y., Tritium transfer from diet to human, J. Radioanal. Nucl. Chem., 197, 271-280(1995)

11) Takahashi, Y., Imaizumi, H., Kano, N., Saito, M., Kato, N., Ishii, Y. and Saito, K., Correlation between tritium and non-sea salt calcium ion con- 
centrations in precipitation, RADIOISOTOPES, $\mathbf{5 7}$, 375-383(2008) (in Japanese)

12) Jiao, Y. R., Ishida, S., Takada, K., Imaizumi, H., Kano, N. and Saito, M., Observation of the movement of the precipitation by using tritium tracer, RADIOISOTOPES, 60, 363-374 (2011)

13) Jiao, Y. R., Imaizumi, H. and Kano, N., Seasonal variation of tritium and major elements in snow and precipitation in Niigata, Japan, J. Environ. Sci. Eng. A1, 10, 1218-1225 (2012)

14) MEXT (Ministry of Education, Culture, Sport, Science, and technology), The manual for analysis of radiocesium Issue No.3 of a Series of Manuals for Measurement of Radiocesium Concentra- tion, Japan chemical analysis center, Chiba, Japan, 21-27 (1976)

15) Saito, M., Isogai, K., Sato, K. and Imaizumi, H., RADIOISOTOPES, 49, 333-338 (2000) (in Japanese)

16) Saito, M., Imaizumi, H. and Takashino, S., Chikasuigijutsu, 43 (11), 1-6 (2001) (in Japanese)

17) Ishii, Y., Saito, M., Imaizumi, H., Kato, N. and Kitaoka, K., RADIOISOTOPES, 63, 79-86(2014) (in Japanese)

18） http ://ja.wikipedia.org/wiki/\%E5\%9C\%B0\%E4\% $\mathrm{B} 8 \% 8 \mathrm{~B} \% \mathrm{E} 6 \% \mathrm{~B} 0 \% \mathrm{~B} 4$

19) http://www.pref.niigata.lg.jp/houshasen/13037 65256257.htm 